\title{
Gender and Tourism Development: A Case Study of the Cappadoccia Region of Turkey
}

\author{
Sermin Elmas
}

\section{Introduction}

During the 1970s, tourism development emerged as an important focus of research and particular emphasis was placed on cross-cultural studies of tourism development and on analysis of inbound tourism's impact on third world countries. At the same time, women's employment also became a 'hot' topic within feminist discourse with many scholars arguing that paid work performed outside the home increases women's economic independence and emancipates them from their marginalization in the domestic domain as reproducers, nurturers and subsistence producers. Thus, development analysts argued that the integration of women into the tourism industry promoted female employment opportunities, developed their work-based skills and fostered 'modern' attitudes. Yet, 30 years later, the question of whether working in tourism does indeed give economic and personal independence to women remains moot. Indeed, many recent studies have clearly demonstrated that from England (Hennesy, 1994) to Greece (Leontidou, 1994), Mexico and the Philippines (Chant, 1997), Bali (Long and Kindon, 1997), Northern Cyprus (Scott, 1997) and beyond, tourism employment actually reinforces existing gender relations and perpetuates inequalities between women and men. Following such studies, this chapter will discuss the nature of women's work in tourism-related services in the Nevşehir-Ürgüp-Avanos triangle in the Cappadoccia region of central Turkey. It attempts to contribute to the growing body of gender analysis within tourism studies by examining the conditions of women's work outside the home (e.g. in hotels, restaurants and handicraftproducing workplaces) and within the home (e.g. in pensions and in handicraft production), as well as analysing the segregation of work between sexes from a gender perspective. In particular it will examine: the conditions of women's participation in social production; their motivations for work; work satisfaction; the various ways in which women are controlled and supervised; their relations with trade unions; and the mechanisms through which existing forms of gender subordination are reproduced in tourism-related organizations, as well as in the women's private lives. 
The chapter reports an extensive study conducted during 1997 and 1998 in the Cappadoccia region, where at the time, there were 91 hotels and pensions, 44 restaurants, 22 travel agencies and 35 touristic handicraft-producing and trading facilities. Since the smaller hotels, city restaurants and travel agencies do not employ women in significant numbers, they were excluded from the study. This meant that the study sample comprised: one first-class motel (the only one in the region); six three-, four- and five-star hotels (from a possible 14); and four pensions (from the 14 in the region). Three of the larger touristic handicraft establishments (which both produced and sold carpets, souvenir onyx products and pottery) were also chosen as they employed relatively high numbers of women compared to other establishments. The sample was completed by two tourist restaurants (from the region's seven), which are registered by the municipalities and four domestic establishments which specialized in handicraft production. In total observations, unstructured interviews and questionnaires were conducted with 80 women working in the selected establishments, whilst 15 managers and owners (all of whom were male) were also interviewed.

\section{The Development of Tourism and Women's Employment in the Cappadoccia Region}

Like other developing countries in the 1980s, Turkey embraced tourism as an important means of implementing the export-led growth strategy recommended by the International Monetary Fund and the World Bank. As a result, in 1982 the Grand National Assembly passed the Tourism Encouragement Law which identified a range of natural, historic and sociocultural criteria necessary for designated touristic areas. Although priority was given to Turkey's coastal regions such as the Mediterranean, Aegean and Marmara, Cappadoccia was also included in this scheme. Thus, the Cappadoccia region has experienced mass tourism development since the early 1980s, primarily initiated by the Turkish government's political and economy strategies (Tosun, 1998). Cappadoccia itself forms a rough triangle, which starts about 169 miles south-east of Ankara and is located between Nevşehir, Kayseri and Niğde. As in many other regions in the country, agriculture dominates the economic sector and whilst small-scale production industries, trade and transportation are important, tourism is the second most significant industry in the region. The regions' main tourist sights are set within a small triangle between Nevşehir, Ürgüp and Avanos and besides its natural and historical attractions it is home to many cultural activities such as handicraft productions.

As a region where women's work is largely unpaid agricultural activity, Cappadoccia provides an interesting case study in which to analyse the impact of paid tourism employment opportunities on women's lives. Women are concentrated predominantly in agriculture and in sub-branches of manufacturing such as carpet-weaving; but since the 1980s, they have also been in demand as employees in hotels, restaurants and in services - a pattern which mirrors women's employment in Turkey generally. Women who left the agriculture sector are now mostly employed in the service sector (Ecevit, 1986) and the percentage of the total female labour force employed in the service sector rose from $14.3 \%$ in 1990 to $28.8 \%$ 
in 2000 (State Institute of Statistics, 2000). Since the tourism industry is seasonal, intensively competitive and labour-intensive and because of the marginal characteristics of women's labour in Turkey (Ecevit, 1992) women's labour is in extensive demand. Whilst the absence of sufficient regional and national statistics makes any estimate of the number of women employed in tourism difficult, we know that in the mid-1990s, women comprised $19 \%$ of employees in accommodation operations, $7 \%$ in restaurants and 36\% in travel agencies (Ministry of Tourism, 1993).

These figures are significantly out of line with those in developed countries where females outnumber males in the tourism sector (Hennesy, 1994; Purcell, 1997; Sinclair, 1997), but these official statistics are endorsed by the findings of the study reported here; for instance, in the five-star hotel that opened in Nevşehir in 1989 women constitute only $14.3 \%$ of the total workforce of 160 employees. In the four-star hotels in the study, female employees constitute $18.9 \%$ of the 273 -strong workforce, whilst in the three-star hotel 6 out of 13 employees are female. In addition to the hotels, a first class motel, which is owned by Tourism Bank, was also studied. This motel has been rented and been in operation since 1983 and women constituted only $16.12 \%$ of the employees. In the two selected restaurants (which are licensed by the municipalities and privately run throughout the year), women make up $10 \%$ of the total staff. Even in the large carpet-weaving enterprise (which are largely made by female workers), only one-third of the total employees are women. These low levels of female employment in tourism-related businesses - even in Ürgüp which is an initiative tourist area - may well be the result less of economic rationality per se, than the familial ideology prevalent in Turkey.

\section{The Proper Place of Women: Familial Ideology and Economic Rationality}

In Islamic societies, the status of women has often been discussed in relation to women's roles, to cultural restrictions such as honour and shame which impact upon women's freedom and in relation to the 'private world of women' and the 'public world of men' (Kağitçibaşi, 1982). Honour, which may refer to a man's reputation in the community as determined by the chastity of the women in his family, is very important and associated largely with women's sexuality (Tucker, 1997). In Turkey, as in other Islamic societies, the familial ideology assigns women to the private domain of home - women are wives and mothers who should be guarded by their husbands, fathers and brothers who are the breadwinners and familial guardians. Thus girls' education (especially higher education) and the degree of their participation in the workforce are determined to a large degree by the permission and control of men, whilst sons are of greater value than daughters and are given priority in accessing resources and education (Göğüş-Tan, 2000). However, the urbanization of Turkey which has accelerated since the 1970s and the hardships which emerged there in the 1980s challenged existing familial ideology and most women in the country have started to work because of economic necessity (Ansal, 1995; Eraydin, 1999). The Cappadoccian women were no exception, although women there were involved in agricultural and weaving activities long before the 1980s as their home-made products were sold and distributed by 
their fathers (when the women were single) or their husbands (when they were married).

As the tourism industry developed and employment outside the home became widespread, women became the best candidates for employment in hotels and especially in the large carpet-weaving enterprises operated by tourism entreprencurs from outside the region. Women from low-class urban families and rural areas soon began working there as paid labourers doing what they used to do at home. But these organizations created environments where both sexes worked side by side, although customs governing male and female work practices - in particular women's confinement to certain activities - remained extremely powerful. Men, not only as parents and husbands, but also as employers tried to allocate women 'appropriate' places. Of course, 'appropriateness' according to employers implies different things in different workplaces. Managers of the bigger hotels prefer to recruit women in departments like reception, food and beverage services and housekeeping. These duties are felt to be compatible with women's 'nature' since they are considered to be more patient than men when confronting customer problems. In food and beverage services, they are seen to be more attractive than men and to create a pleasant image of the hotel or restaurant in the eyes of customers. Finally, in the housekeeping department, women are preferred to men since they are familiar with the tasks they do at the hotel. This last point is also evident in the large carpet-weaving enterprise and in both the pottery and the onyx processing workshops. On the other hand - in the eyes of managers - as women's productivity is less than that of men in physically demanding tasks and as they are thought to be more defenceless when confronting problems, it is not considered to be appropriate to employ them as cooks, night officials, security staff and waiters. Thus, 'appropriateness', according to employers, implied two things: first, a male job is not appropriate for women because women could not undertake it due to their physical weaknesses; second, it is not appropriate (such as in night services) because women must not perform it due to moral reasons.

As a result of the values and beliefs characteristic of Turkish society, many of the women in this study were not able to ask why they worked in a specific situation, although they do know why they work outside their houses. Except for a minority of women who were educated and employed in relatively high organizational levels and those who were developing their craft skills in workplaces with the intention of operating their own businesses in the future, for $86 \%$ of the women there was no other reason for taking a job outside the home other than economic necessity. It is also evident that, aside from their desire to remain in the private domain and focus on their responsibilities as wives and mothers, over $90 \%$ of female seasonal workers working in hotels and restaurants would work as full-time year-round employees. In other words, if their employers offered them work all year, each year, they would not leave their workplaces as they would not need to look for alternative employment at the end of the season - clearly the duration of their employment in the same establishment depends not on them but on the demands of their employers. For women who work seasonally and are only employed for approximately 6 months the most important question is: Will I be employed when the new season starts? Although there is a legal requirement for Turkish businesses to re-employ previous staff the following season (Koray, 1999), 
seasonal female hotel workers in the study indicated that their continued employment in the same establishments depends on their employers' discretion. For those who had not been so re-employed, whilst some had found alternative employment in other hotels, 38\% remained unemployed and dependent on their husbands or families and $17 \%$ had turned to informal employment such as making lace to sell to tourists.

As other studies undertaken in Turkey indicate (e.g. Ecevit, 1991), in largerscale (as opposed to family-run) businesses, economic considerations are the primary determinant in structuring the nature of women's participation in the workforce and female staff turnover is more related to their insecure working conditions than to their individual characteristics. In this study, almost all of the women working seasonally in hotels wanted permanent employment and its associated benefits of social security and retirement payment. They were denied this as a result of a number of factors including the insecurity of the tourism labour market, a lack of investment in the sector and the limited employment capacity of tourism businesses as a result of the industry's seasonality. All of these - in combination with the familial ideology which assigns women to the private domain of home - force women into the informal tourism sector and drives down the wages paid to them by the larger tourism operators. This picture contrasts sharply with the situation in the family-based handicraft-producing organizations and pensions, where all the women performed unpaid work which they described as 'helping' their husbands. As married women they considered that they should be alongside their husbands in times of prosperity and hardship and perceived their labour not as work which should be remunerated but as 'help' for the benefit of their families - done as one of the requirements of marriage.

\section{Gender-based Work Segregation and the Division of Labour}

The study identified gender-based horizontal and vertical segregation in all the larger-scale tourism-related businesses in the region. Typically, in the hotels, women were concentrated in the housekeeping department as unskilled cleaners, whilst the more educated ones were employed in the front office as receptionists. In contrast, men typically worked as skilled or semi-skilled workers in food production, maintenance and repair services and security, whilst the food and beverage department was exclusively the domain of women. In the restaurants, local women tended to work as unskilled cleaners, whilst the men were employed as cooks and waiters alongside waitresses who were usually young and single tourism students from other regions of Turkey. In the carpet-weaving enterprise, of the 75 female employees over $86 \%$ worked in the production department, whilst most $(95 \%)$ of the 125 male staff worked in the marketing department with a small number of female secretaries. In the small pottery and onyx processing workshops, the men were the master craftsmen who transformed the raw material into products, whilst the women were responsible for the product decoration and painting and for the retail sale operations.

Such gender-based horizontal segregation is typical of much tourism employment worldwide, as is the vertical gender-based segregation which also character- 
izes these organizations in the Cappadoccia. This study shows that women were not employed in the higher levels of the businesses and that it is men who hold the responsible positions in the hotels, restaurants, large carpet-weaving establishments and workshops as managers and owner-managers. Even in the hotel housekeeping departments - where the female employees were concentrated - only one woman occupied a management position. In all the other hotels in the study, the highest positions women occupied were housekeeping supervisors or in front-office and reception jobs. Even in the large carpet-weaving establishment (where women predominate), only five women were supervisors and instructors, whilst a male manager supervised these skilled supervisors as well as the other semi-skilled female weavers.

It emerges from the study that the allocation of men and women to particular jobs in the larger tourism-related businesses is done on the basis of attributing certain characteristics to both the jobs and each gender. Typically, men were found to occupy positions as managers, owners, salespersons and technical staff - all jobs which are valued within the organizations. In contrast, women's jobs were typically categorized as unskilled, easy and unimportant since according to managers - and even the women themselves - they perform jobs which are similar to their unpaid domestic work. In this respect, the tourism industry mirrors the general position of Turkish women who work in labour-intensive industries; thus in Turkey, following textiles, those industries which have the highest concentration of female workers are tobacco, food, garments and chemical. Just as in tourism, all these sectors are seen to be 'most suited to women as they are an extension of the work women do at home' (Ecevit, 1986, p. 123). Likewise, cleaning and serving food in hotels and restaurants are commonly defined as women's work and are seen as extensions of women's domestic tasks and responsibilities. Even though female cleaners have skills and do require training, these occupations are not classified as skilled because they are identified with women, whilst at the same time, the association of women with unskilled jobs further devalues women's work. Interestingly, when tasks such as cooking - which are among the primary domestic duties of women - are performed in hotels and restaurants by men, they are taken seriously and classified as skilled jobs. In such ways are the male and female labour forces differentially valued, classified and rewarded in the larger tourism businesses.

In the family-based small organizations (such as pensions and dwellings where bibelots are produced for sale to tourists), there was a division of labour between spouses in the production process and a detailed examination of the four pensions sampled in the study reveals that whilst two were run by both paid-workers and unpaid family members, the other two operated on the unpaid labour of wives. The first pension, operated by a husband and wife couple in Avanos, has six rooms with 16 beds. Both spouses are retired teachers and they divide their labour so that the husband deals with the pension's management, booking, accounting and servicing, whilst his wife is responsible for the cooking, cleaning and shopping with the unpaid help of a 14-year-old boy from a poor, rural family who works throughout the tourism season (from April until early September or October) in return for which the couple pay his school expenses. The second pension is larger - with 12 rooms and 45 beds and relies on a wife who works as an unpaid family worker responsible for the cooking, whilst two women are employed seasonally to undertake the cleaning. 
The third pension - with ten rooms and 30 bed capacity - operates in Avanos with two paid seasonal female cleaners and the owner's wife and two sons as unpaid family workers. While the owner's wife prepares the meals, the two sons (aged 18 and 23), regarded as its future operators, deal with service activities and assist their father who manages their pocket money in return of their help in the pension. Finally, the fourth pension - this time in Ürgüp - has eight rooms with 20 beds and is operated by a husband and wife, together with their two sons and two daughters-in-law. Here again, there is a clear division of labour based on gender, with men dealing with the managerial, service and technical affairs, whilst the three women cooked and cleaned. Such a gendered division of labour was also apparent in the four small bibelot-producing workshops investigated in the study. Located in the producers' homes, these were operated by husband-and-wife couples and while the husbands bought the raw materials from dealers, bargained with traders and produced the raw bibelots, painting them and arranging them for retail was the responsibility of their wives.

It seems as though, just like the larger tourism-related businesses, the region's family-run businesses also reinforce traditional gender-based divisions of labour so that men take responsibility for the management of the business and any external negotiations whilst women contribute their unpaid domestic labour. Although it emerges that whilst women are under the control of their husbands, young men are also under the control of their fathers; young men's rewards for working in these family-run establishments are very different from their mothers' or wives'. In pensions, most of the day-to-day work is carried out by women, including tasks such as cooking and serving meals, cleaning rooms, providing tea or coffee during the day, doing the laundry and shopping for food whilst the men engage in activities such as negotiating room prices and for those services provided by the female household members. However, whilst the women work as unpaid family workers, the owners' sons - whose pocket money was managed by their fathers - clearly regarded themselves as future owners of these establishments. In contrast, as Scott (1997) has argued elsewhere, women's rewards for working in their own family-run accommodation businesses are merely an increase in domestic work, longer working hours and a decline in opportunities for social interaction with their neighbours and kin. Clearly, in these family establishments, the overlapping roles and responsibilities of work and family are closely tied to traditional expectations and responsibilities associated with gender roles and the continuing position of men as providers and of women as homemakers (despite their obvious contributions to the success of the businesses) reinforce the myths of separate worlds.

\section{Women, Social Control, Capitalism and Patriarchy}

One of the key characteristics of tourism is that it is a highly labour-intensive industry and thus one of the main ways in which employers can increase their profits is to reduce labour costs by lowering wages. Taken in combination with the fact that Turkey is a society where women's social status is determined mainly by customs, traditions and religion, this means that women's main role as homemakers and men's roles as breadwinners are often used by employers to justify paying women 
lower wages relative to men (Ecevit, 1991). In other words, although many working women are the sole wage earners in their families, their low wage levels are justified by their assumed dependence on men who are supposed to support them. In this study, it was found that except in the state-owned first-class motel and the five-star hotel (which had collective bargaining through trade unions) staff wage levels in the accommodation sector were set by the establishments' managers and were open to their subjective judgements. In the craft workshops the female weavers' wages were determined by the price and the number of the knots they tied each day for the carpets. This piecework payment (instead of a weekly or monthly wage) is justified by the employers on the basis that it produces a harder working and thus more productive workforce.

Traditionally workers would look to trade or employee unions to uphold their interests, but the hospitality industry has a low rate of unionization across the world (Hennesy, 1994; Sinclair, 1997). This is principally a result of the high numbers of part-time and seasonal workers in the sector, both of which are traditionally difficult to unionize and organize. Such workers are often denied the same employment rights enjoyed by full-time staff and they may consider it less worthwhile to join a union for a limited period of time (Urry, 1990). In addition, a number of studies have shown that in Turkey, although women are concentrated in certain manufacturing industries such as weaving, food processing and metallurgical industries and in service industries, especially education, banking, accommodation and entertainment (Toksöz, 1998), they are less unionized than men, only constituting 9\% of all Turkish trade union members (Ecevit, 2000).

As was mentioned above, the only workers in this study who were trade union members worked in the five-star hotel and the state-owned first class motel. In the five-star hotel $84 \%$ of the male (137) and $61 \%$ of the female staff (23) were trade union members, although none of the seasonal workers was unionized. In the stateowned first class motel all personnel - whether full-time or seasonal - were trade union members. However, although all the female employees were trade union members none of the women interviewed in this study participated in union activities. This lack of participation was the result of three factors - the women's familial obligations, the negative attitudes of their managers and their own lack of commitment to the trade union. Most of the women believed that trade unions are not interested in any of their problems, with the exception of wage regulations, a finding which endorses other studies of female trade union membership patterns in Turkey (Eser, 1997; Koray, 1999). Such studies suggest that the trade unions are insensitive towards female employees' problems and in particular, fail to support them their struggles against sex segregation, for a fairer distribution of jobs, for more childcare facilities and for work-based training (Ecevit, 1991). This insensitivity towards women's problems make trade unions unattractive for even young single women who might otherwise be prepared to become active union members.

Taken as a whole therefore, a number of key issues emerge from the study. First, across the board women's wages are depressed relative to their male counterparts; second, women who work in larger organizations in the tourism sector generally have better working conditions as they operate under the aegis of labour legislation; third, in labour-intensive sectors such as tourism and the related craft establishments, wages account for a significant proportion of production costs and 
the control of wages is seen as central to increased productivity and work quality; and finally, that 'gender identity is [also] crucial' (Ecevit, 1991, p. 68) in determining horizontal and vertical labour divisions with the tourism and tourism-related sector. As we have seen, even in those departments and businesses where women form the majority of the workforce, most supervisors and line managers are men, who are seen to exhibit attributes and characteristics (such as aggression) which are considered appropriate for management responsibilities.

A further dimension to the position of women employees in tourism-related businesses in Turkey is their 'invisibility'. By this I mean that, in establishments like hotels where recruitment depends on informal relations, the owners or managers practise 'control' over their female employees by rendering them invisible, particularly to the external world. In Turkey, there is considerable social control over a woman's sexuality since this control is seen as not belonging to the woman herself. Thus many individuals see themselves as directly responsible for policing women's sexual behaviour, including not only parents and brothers, but also relatives and neighbours who actively scrutinize adolescent girls' behaviour (Kandiyoti, 1997). This is translated into the tourism context so that, many male accommodation operators not only strictly control their wives' and daughters' interactions with customers but also monitor the behaviour of single Turkish female guests staying in their pensions: whilst a Turkish man may rent a room for one or more nights with his foreign girlfriend, a single Turkish woman could not do the same and would even have to observe a curfew set by the pension owner for returning to the room at night.

Tucker (1997, p. 113), in her study in Göreme - a district of the Cappadoccia region - argues that 'tourists never have contact with Turkish women and the interaction with tourists is strictly the domain of men'. Whilst this is true in many instances, it should also be pointed out that young (and often attractive) Turkish women are also favoured for some jobs such as hotel receptionists which require intensive interactions with both local and foreign men. However, in such circumstances, both the employers themselves and the women's male co-workers consider that they have a key role in reinforcing the women's sexual identity and policing their sexual conduct. In the small enterprises in the study, especially in the accommodation and restaurant businesses, employers exercised strict control over their female staff. Moreover, whilst young local waiters worked alongside women in restaurants, these were not local waitresses but young, single tourism students from outside the region who were working to gain experience and to earn money for their school expenses. The hotel managers explained that the lack of local women working as waitresses in their restaurants was due to the attitude of their families. Despite living in hardship, they did not allow their daughters to work as waitresses as they thought that a mixed gender workplace would inevitably lead to sexual and emotional liaisons between staff. Other restaurant managers also suggested that the customer interactions necessary for waiting on tables were unsuitable for women as such service situations had connotations attached to the role of a hostess and were thus perceived to be associated with prostitution. Given these perceptions it is not surprising that women do not tend to work in restaurants in Turkey. Moreover, such attitudes also illustrate the complex relationship between sexuality, the construction of women's position in society and workplace practices and interactions. 
It is also interesting that opposition to the employment of women as waitresses comes not only from their families and employers but also from their male coworkers. Several of the waitresses interviewed in this study said that they had experienced hostility from male colleagues as a result of the competition caused by tipping. Such competition between the waiters and waitresses is also overlain and complicated by the existing patriarchal ideology.

\section{The Private Lives of Working Women}

Whilst this study has so far focused on workplace practices, such an exploration would not be complete without a discussion of family dynamics since the interdependence of work and family is closely tied to expectations and responsibilities associated with gender roles. Thus, as we have seen, the traditional view of men as providers and of women as homemakers reinforces the myth of separate worlds. The study found that the division of labour among family members in the region follows traditional arrangements. Thus, the women shoulder the major burden for running the household: $80 \%$ of married women stated that their husbands did not share responsibility for any household chores other than paying the bills. This was true even in the households of women who worked at higher levels in organizations and in pensions where the wives' labour was crucial to the businesses' operation: clearly, a woman's entry into the workforce does nothing to alter her domestic burdens and responsibilities. Perhaps the most important domestic responsibility for working women, however, is childcare. In this study, over $80 \%$ of working women had children over pre-school age, whilst a further $17 \%$ had children under 6 years and thus needed their relatives' support as there are no childcare facilities in the women's workplaces. However, with the help of female relatives and neighbours, childcare does not seem a very salient issue for working women, although of course, child-rearing necessarily disrupts their participation in the labour market. Moreover, as earlier studies (Abadan-Unat, 1982; Duben, 1982) have noted, solving the childcare problem in this manner also reinforces the informal sector support systems, strengthens traditional family patterns and the gender-based division of labour.

Interestingly, many of the women in the study commented that employed wives had more familial power than full-time homemakers, not only in terms of financial decision making (see Vaydanoff, 1987), but also in decisions concerning women's employment, their physical mobility, their children, purchasing decisions and decisions concerning invitations for relatives, friends and others. However, notwithstanding this, the study also found that women still have less power relative to men. Whilst the men did not always share in some decisions which are traditionally considered the women's domain (such as hosting visitors), they continue to dominate in making important decisions over matters such as women's employment, physical mobility, children's education and marriages, expenditure on furniture and on other larger items. Thus, whilst the opportunities created by tourism development in the region has increased the number of women in the workforce and a growing number of families have come to rely on the contributions of working women to maintain an adequate living standard, many of the single women 
could not spend their salaries freely and almost all of the salaried working women contributed to a family budget, only reserving a small proportion of their wages for themselves. Significantly, much of these women's salaries help to pay for their families' cars, trucks and houses - all of which are registered to their husbands due to their commitment to the popularly held belief that everything in married life is held in common.

One of the key benefits of working outside the home, however, for the women springs from the social aspects of their work environment and the self-confidence, friendship and sense of belonging which this provides. In contrast those who work at home who spoke of their feelings of isolation, almost all the women working outside the home pointed out that their work environments provide opportunities for social interaction and that their status as wage-earners (whatever their wage levels) had a positive impact on their perceptions of self and their outlook on the world. While most of the women commented that they did not enjoy their working conditions, they did attach social and psychological value to their working lives and derive considerable work satisfaction. Thus, this study endorses the findings of Özgen and Ufuk (1998, p. 286) who have commented that 'social relationships within the workforce are one of the most important factors regarding work satisfaction of women'. It seems, therefore, that whilst women's traditional familial roles remain strong, many of those in this study derived significant self-confidence from working outside the home, many saying that it reduced their sense of isolation and some commenting that their status as contributory or even sole wage-earners in the family enabled them to respond to their husbands' domestic violence.

\section{Conclusion}

This study has explored the changing patterns of women's employment in Cappadoccia as a result of the expansion of the region's tourism industry since the 1980s. Although such employment has been seen to offer significant benefits to women's lives, it also emerges that the structure and characteristics of tourism in the region, together with the continuation of traditional gendered roles, denies women access to the labour market on the same terms as men. The larger commercial tourism employers tend to allocate women jobs based on their genderascribed characteristics and supposed personality traits. Such patriarchal control dictates that men are much more likely to be employed as managers, owners and sales or technical staff and their jobs are considered more valuable to the running of the organization. Likewise within family-run organizations, if jobs can be arbitrarily described as skilled or unskilled, difficult or easy and important or unimportant, it is always the women's jobs which are categorized as unskilled, easy and unimportant since they tend to replicate their domestic duties. At the same time, whilst educational level is a determinant of the type of jobs available to women, they tend to be recruited into those areas where there are less advancement opportunities. Women are ghettoized into departments which utilize their traditional domestic skills and thus employers can justify not offering training programmes and thereby further reduce their training costs. Moreover, the study suggests that increased opportunities to work as paid employees outside the home 
(often below the minimum wage level and without any job security) has also done little to fundamentally alter the domestic power balance. Women are not decision makers in important familial issues, they are not property-owners, their mobility remains strictly controlled by their husbands and they have little time or money to spend on leisure activities. What working outside the home (instead of working as unpaid workers in family-run businesses) does offer many women, however, is as paid social interaction with other women and a considerable amount of self-esteem. Thus, whilst paid employment in the tourism sector has increased the burden of the 'double shift', the separation of family life and workplace has also brought psychological and social benefits to these women in the Cappadoccia region, as elsewhere in Turkey.

\section{References}

Abadan-Unat, N. (1982) Social change and Turkish women. In: Abadan-Unat, N. (ed.) Women in Turkish Society. E.S. Brill, Leiden, The Netherlands.

Ansal, H. (1995) Çalışma Hayatında Cinsiyetçilik ve 1980lerde Türk Sanayiinde Ücretli Kadın Emeğinin Değişen Konumu. Toplum ve Bilim. 66, Bahar, 17-66.

Chant, S. (1997) Gender and tourism employment in mexico and the Philippines. In: Sinclair, M.T. (ed.) Gender, Work and Tourism. Routledge, London.

Duben, A. (1982) The significance of family and kinship in urban Turkey. In: Kağıtçıbaşı, Ç. (ed.) Sex Roles, Family and Community in Turkey. Indiana University, Turkish Studies 3.

Ecevit, Y. (1986) An analysis of the concentration of women wage workers in Turkish manufacturing industries. Women, Family and Social Change in Turkey. UNESCO, Bangkok.

Ecevit, Y. (1991) Shop floor control: the ideological construction of Turkish women factory workers'. In: Redclift, N. and Sinclair, M.T. (eds) Working Women: International Perspectives on Labor and Cender Ideology. Routledge, London.

Ecevit, Y. (1992) Türkiye'de Kadın İşgücünün Marjinalliği. Bülten Dergisi. Türk Demokrasi Vakfı Yayın Organı, Nisan, Sayı:11, 15-34.

Ecevit, Y. (2000) Çalışma Yaşamında Kadın Emeğinin Kullanımı ve Kadın Erkek Eşitliği. Kadın-Erkek Eşitliğine Doğru Yürüyüş: Eğitim, Çalışma Yaşamı ve Siyaset. TÜSiADT/2000-12/290, İstanbul, Türkiye.
Eraydin, A. (1999) Yeni Üretim Süreçleri ve Kadın Emeği. T.C. Baş bakanlık Kadının Statüsü re Sorunları Genel Müdürlüğü, Ankara, Türkiye.

Eser, Ş. (1997) Part-time Çalışmanın Türkiye'de Kadın Istihdamına Etkisi. T.C. Başbakanlık Aile Araştırma Kurumu Yayınları, Ankara, Türkiye.

Göğüş-Tan, M. (2000) Eğitimde Kadın-Erkek Eşitliği ve Türkiye Gerçeği. Kadın-Erkek Eşitliğine Doğru Yürüyüş: Eğitim, Çalışma Yaşamı ve Siyaset. TÜSIAD-T/2000-12/290, istanbul, Türkiye.

Hennesy, S. (1994) Female employment in south-west England. In: Kinnaird, V. and Hall, D. (eds) Tourism: A Gender Analysis. Wiley, Chichester, UK.

Kağıtçıbaşı, Ç. (1982) Sex roles, value of children and fertility in Turkey. In: Kağıtçıbaşı, Ç. (ed.) Sex Roles, Family and Community in Turkey. Indiana University, Turkish Studies 3.

Kandiyoti, D. (1997) Cariyeler, Bacılar, Yurttaşlar. Metis Kadın Araştırmaları Yayınları, İstanbul, Türkiye.

Koray, M. (1999) Gıda İşkolunda Çalışan Kadınların Koşulları ve Geleceği. T.C. Başbakanlık Kadın Statüsü ve Sorunları Genel Müdürlügü, Ankara, Türkiye.

Leontidou, L. (1994) Gender dimensions of tourism in Greece: employment, subcultures and restructuring. In: Kinnaird, V. and Hall, D. (eds) Tourism: A Gender Analysis. Wiley, Chichester, UK.

Long, H.V. and Kindon, S.L. (1997) Gender and tourism development in Balinese villages. In: Sinclair, M.T. (ed.) Gender, Work and Tourism. Routledge, London. 
Ministry of Tourism (1993) Manpower Survey of the Hotel and Tourism Industry, Ministry of Tourism/ILO, Turkey, Ankara.

Özgen, Ö. and Ufuk, H. (1998) Kadınların Evde Gerçekleştirdikleri Girişimcilik Faaliyetlerinin Aile Yaşamına Etkisi. In: Çitçi, O. (ed.) 20. Yüzyılın Sonunda Kadınlar ve Gelecek. TODAIE, Ankara, Türkiye.

Purcell, K. (1997) Women's employment in UK tourism: gender roles and labor markets. In: Sinclair, M.T. (ed.) Gender, Work and Tourism. Routledge, London.

Scott, J. (1997) Chances and choices: women in Northern Cyprus. In: Sinclair, M.T. (ed.) Gender, Work and Tourism. Routledge, London.

Sinclair, M.T. (1997) Issues and theories of gender and work in tourism. In: Sinclair, M.T. (ed.) Gender, Work and Tourism. Routledge, London.
State Institute of Statistics (2000) Household Labor Survey: Turkey, Ankara, State Institute of Statistics.

Toksöz, G. (1998) Türkiye'de Sendikal Kadın Kimliği. In: Çitçi, O. (ed.) 20. Yüzyılın Sonunda Kadınlar ve Gelecek. TODAIE, Ankara, Türkiye.

Tosun, C. (1998) Local Community Participation in the Tourism Development Process: The Case of Ürgüp in Turkey. Unpublished PhD thesis. The Scottish Hotel School. University of Strathclyde, UK.

Tucker, H. (1997) The ideal village: interactions through tourism in central Anatolia. In: Abram, S., Waldren, J. and Macleod, D.V.L. (eds) Tourists and Tourism: Identifying with People and Places. Beng, Oxford.

Urry, J. (1990) The Tourist Gaze: Leisure and Travel in Contemporary Societies. Sage, London.

Vaydanoff, P. (1987) Work and Family Life. Sage, Beverly Hills, California. 